\title{
Sequential battery of COVID-19 testing to maximize negative predictive value before surgeries
}

\section{Bateria sequencial de testes para COVID-19 para maximizar o valor preditivo negativo antes de operações}

\author{
Neeraj Sinha'; Galit Balayla² ${ }^{1}$.
}

\section{A B S T R A C T}

\begin{abstract}
SARS-COV-2 is a novel virus which has proven to be highly contagious. Specific viral dynamics and immune response to the virus are yet to be fully defined and determining the sensitivity and specificity of the available testing methods is still a work in progress. This study examines the published information on the testing methods, and finds that yield of COVID-19 tests changes with specimen types and with time through course of illness. We propose a sequential battery of testing consisting of an epidemiologic survey, RT-PCR tests, serologic tests and chest CT on surgical candidates which may increase the negative predictive value, and facilitate surgical procedures.
\end{abstract}

Keywords: Transplants. Coronavirus. Predictive Value of Tests.

\section{INTRODUCTION}

$T_{2}^{\text {ne }}$ he SARS-CoV-2 outbreak started on December 2019 in Wuhan, China and quickly became a global pandemic. Good testing methods are essential to control any pandemic; however, due to the quick viral spreading of the novel virus, current testing lacks good sensitivity and specificity, failing to truly discriminate the positive cases from the negative patients. An elective surgery on a patient with undiagnosed COVID-19 infection can worsen patient outcomes and expose health care workers. This is a systematic review of the published literature to try to understand the viral dynamics and immune response of the COVID-19 virus, and suggest how to better implement the available testing in order to decrease the false negative rate, especially on patients undergoing surgery during this pandemic.

\section{METHODS}

We searched the PubMed and google scholar data base for articles on SARS-CoV-2, diagnostics and surgeries. We searched terms "COVID-19 testing", "COVID-19 transmission routs", "COVID-19 serology", "COVID-19 PCR", "COVID-19 clinical characteristics", "sensitivity and specificity", "COVID-19 immune response", "SARS-CoV-2 viral shedding", "COVID-19 and transplant", "COVID-19 and surgeries", "ELISA testing". We screened the results of more than 140 articles according to title and abstract, and scanned useful references cited on these articles retrieving those more suitable for the study. We referenced 72 articles, including the World Health Organization and CDC guidelines. The last search was made on April 19th, 2020. 


\section{DISCUSSION}

\section{Clinical characteristics of COVID-19 virus}

In December 2019, a cluster of pneumonia cases associated with a food market was reported in Wuhan, China. The underlying cause was identified as a novel betacoronavirus originally named 2019-novel coronavirus (2019-nCoV) by the World Health Organization (WHO) and later renamed COVID-19 (SARS-CoV-2). In March 2020, the WHO declared the outbreak a pandemic. To this date: April 19th, 2020, there have been 2,241,359 globally confirmed cases, 152,551 deaths and more than 190 countries affected ${ }^{1}$. The clinical characteristics of the virus can vary from asymptomatic patients to patients presenting with fever (83-99\%), cough (59$82 \%)$, fatigue $(44-70 \%)$, anorexia $(40-84 \%)$, shortness of breath (31-40\%), sputum production (28-33\%), myalgias $(11-35 \%)$, sore throat $(13.9 \%)$, headache $(13.6 \%)$, diarrhea $(3.8 \%)$ and vomiting $(5 \%)^{2,3}$. A multicenter study conducted in Europe reported $85.6 \%$ olfactory dysfunctions and $88 \%$ gustatory dysfunctions in patients with COVID-19 that appeared in $11.8 \%$ of cases as an early symptom of the disease ${ }^{4}$. The illness may vary between mild ( $81 \%)$, severe $(14 \%)$ and critical $(5 \%)$. The case fatality rate differs between countries ${ }^{5}$ and the cause of death is usually due to acute respiratory distress syndrome leading to respiratory failure ${ }^{6,7}$, but arrhythmias, shock, acute kidney dysfunction and liver dysfunction have also been reported as death cause ${ }^{3}$. Severity has been seen mostly in the elderly population and patients with underlying diseases such as diabetes, hypertension, and pulmonary conditions, but fatalities have also been reported in young patients ${ }^{7,8}$.

\section{Transmission routes}

According to current evidence, COVID-19 virus is primarily transmitted between people through respiratory droplets and contact routes. Droplet mode of transmission occurs when a person is in close contact with someone infected, exposing their mucosae to the droplets. One of the first descriptions of this route was published by Qun Li et al. that estimated an RO of approximately 2.2 , which means that on average, each patient has been spreading the infection to 2.2 other people $^{9}$. Studies from several clusters of families have confirmed the theory of close contact transmission, even if the contact was brief ${ }^{10,13}$. The first case of person-toperson transmission in the United States was reported in Illinois and was published by Lancet, describing the case of a male patient who was infected when his wife returned from a trip to Wuhan, China ${ }^{14}$. The powerful infectivity of this novel coronavirus might be explained by the new findings from Wrapp $D$ et al. demonstrating a higher affinity of the novel SARS-CoV-2 virus to the angiotensin enzyme 2 (ACE2) receptor than the previous SARS-CoV ${ }^{15}$. Another transmission route that has been suggested is through contact. Interaction with infected surfaces followed by mucosal contact with contaminated hands might also transmit the virus. One study reported both SARS-CoV-2 and SARS-CoV presence up to 72 hours on plastic and stainless steel ${ }^{16}$. Kamp et al. tested the presence of other types of coronavirus on several surfaces and detected their permanence to up to 9 days, suggesting that COVID-19 might behave similarly ${ }^{17}$. Airborne transmission refers to the microbe presence in the nuclei of particles with a diameter of $<5 \mu \mathrm{m}$ that can remain in the air for longer periods of time than droplets and be transmitted at greater distances. COVID-19 airborne transmission may occur during the performance of procedures that generate aerosols like endotracheal intubation, bronchoscopy or tracheostomy70. In addition, viral shedding on fecal samples has been reported on multiple patients indicating that the virus may replicate in the gastrointestinal tract, suggesting a probable fecal-oral transmission ${ }^{18,19}$.

The incubation period of an infectious disease is defined as the elapsed time from the moment a person is exposed to an infective agent and the appearance of signs and symptoms. For COVID-19, the incubation period is thought to extend up to 14 days, with a median of 4-5 days from exposure to symptomatic onset ${ }^{9,20,21}$. Several small cluster studies have suggested viral transmission from asymptomatic patients by conducting epidemiologic studies on this population ${ }^{9-10,13,22-26}$. One of the patients that contracted the infection from an asymptomatic patient in Germany had a high sputum viral load after symptoms disappeared, also raising concerns 
of the presence of viral shedding even after symptomatic recovery ${ }^{25}$. Furthermore, Zou et al. reported that the viral load detected in asymptomatic patients was similar in symptomatic patients, and viral loads from patients with severe disease were higher than those with milder presentation ${ }^{27}$. A study conducted in Shenzhen, China, identified and isolated 55 asymptomatic patients with SARS-CoV-2 after a family member tested positive for the virus. 14 patients developed mild disease, 39 developed moderate disease and 2 developed severe disease. The two patients that developed severe disease represent a $3.9 \%$ conversion rate, which is highly concerning, since asymptomatic patients are usually not detected early ${ }^{28}$. The fact that asymptomatic and recovered patients may spread the virus is worrisome, not only for the epidemiologists trying to implement measures to avoid the spread, but for health care workers evaluating their patients without personal protective equipment ${ }^{29}$.

\section{Viral shedding Pattern}

The actual shedding pattern of COVID-19 is yet to be determined. However, real time RT-PCR is being used to detect viral presence in patients. The viral load can peak as early as one day before symptom onset or 5-6 days after, with a median viral load of $5.2 \log 10$ copies/ $\mathrm{mLI}$ at presentation, and then start declining ${ }^{38}$. This suggested shedding pattern seems similar to the one of influenza virus which is more contagious than SARS-CoV that usually peaks around day 10 of symptom onset ${ }^{27,30}$. One study determined that the median duration of SARSCoV-2 viral shedding was 12.0 days, the shortest being 4 days and the longest 34 days $^{31}$. Another retrospective study conducted in China, evaluated 191 patients. For survivors, the median duration of viral shedding was 20 days, the shortest being 8 days and the longest 37, while in non-survivors, viral load was present even after death. Furthermore, when classified by severity, the median duration of viral shedding in patients with severe disease and critical disease was 19 days and 24 days respectively ${ }^{32}$. This is consistent with results from Yang Liu et al. who found early viral clearance in mild cases in contrast to severe cases, who tested positive beyond day 10 post symptom onset, which would indicate that viral load may predict severity and prognosis to COVID-19 patients $^{33}$

Higher viral loads have been detected in the nose and saliva compared to throat samples ${ }^{27}$. One study of 205 patients, showed highest positivity rates in bronchoalveolar lavage fluid (93\%) and sputum (72\%), followed by nasal swabs (63\%), pharyngeal swabs (32\%), feces (29\%) and blood (1\%). Two patients had live SARS-CoV-2 on feces sample which may corroborate fecal-oral transmission ${ }^{34}$. Wei Zhang et al. suggest a shift in PCR molecular positivity throughout time. They detected that on day $0,80 \%$ of oral swabs were positive, but by day 5 , only $50 \%$ of oral swabs were positive in contrast to $75 \%$ of anal swabs. Moreover, 6 patients that tested negative on day 0 became positive by day 5 , especially by anal swab ${ }^{35}$ The average viral RNA conversion time was 18.2 days on nasopharyngeal swab and 19.3 on feces ${ }^{19}$, corroborating the time shift seen in tissue samples. However, further studies are warranted to assess if PCR positive patients are still shedding live and transmissible virus during the recovery phase like in the incubation phase. Until more compelling conclusions can be drawn, patients should be isolated for 14 days after testing positive for SARS-CoV-2 RNA and better safety measures should be taken when manipulating any sample.

\section{Antibody response to COVID-19}

A The immune response is vital for the control and resolution of infectious diseases, with the antibody response being the main indicator of the disease status and provided immunity. IgM antibody usually indicates acute disease, while IgG antibody indicates chronic or recovered disease. However, the kinetics of the immune response to COVID-19 infection are still not well understood.

One study analyzed both humoral and cellular immune response of one non-severe COVID-19 patient, stating that antibody secreting cells (ACS) with IgM and IgG SARS-CoV-2- binding antibodies and activated CD4 and CD8, were present in the patient's blood before resolution of symptoms. ASC ACS and both $\lg G$ and IgM appeared in the blood on day 7 at the time of viral clearance, confirmed by PCR, and the antibodies were still present by day $20^{36}$. Some studies suggest the presence 
of antibodies between 7 and 11 days post-exposure, while other studies describe the presence of antibodies as early as the first day of symptoms ${ }^{40,42}$. Li Guo et al. described the presence of $\lg \mathrm{M}$ and $\lg \mathrm{A}$ in $85.4 \%$ and $92.7 \%$ of patients respectively between $0-7$ days postsymptom onset. The levels of IgA and IgM increased between 8-14 days but did not increase further between days 15 and 21 . They did not describe the detection rate after the 26th day due to the limited number of patients available. The median time of IgG appearance was 14 days since the initiation of symptoms. IgG levels continued to rise until day 20 and after the 21 st day, the levels plateaued ${ }^{37}$.

Several studies have described a greater and earlier positivity rate of IgG over IgM. One study stated an IgM positivity rate increase from $50 \%$ to $81 \%$ in contrast to lgG that increased from $81 \%$ to $100 \%{ }^{35}$. Another study indicated that more patients had earlier and longer seroconversion of $\mathrm{IgG}$ in comparison to IgM, for both anti-receptor binding domain (RBD) and anti-internal nucleoprotein (NP) ${ }^{38}$. Furthermore, a study conducted in China tested for antibodies on 60 convalescent patients 6-7 weeks after onset of symptoms. All patients tested positive for IgG antibody while 13 patients tested negative for IgM. From the 47 patients that tested positive for the two antibodies, they re-tested 10 patients a week later, demonstrating the presence of both $\operatorname{lgM}$ and $\lg \mathrm{G}$ antibodies but with lower titers. These 10 patients also had two consecutive SARSCoV-2 negative RNA RT-PCR tests and improvement on the $\mathrm{CT}$. The clinical improvement with the positivity in serologic testing might suggest that antibody detection could indicate the stage of COVID-19 progression ${ }^{39}$. However, the SARS-CoV-2 antibody dynamics through time is not yet well determined.

Even though serum antibody presence has been positive, until this date it has not been confirmed that these antibodies clear SARS-CoV-2 virus effectively, provide long-term immunity and/or prevent reinfection. One study noted that a rise in antibodies was not necessarily accompanied by RNA clearance, especially in critical patients. This suggests that antibodies may not be sufficient to clear the virus ${ }^{40}$. However, a longitudinal study of SARS-CoV-2 in macaques showed that if the monkeys produced enough antibodies at an early stage of the disease, they would not be contagious nor be re-infected by the virus ${ }^{41}$. However, more studies are warranted throughout time to accurately understand the immune response to SARS-CoV-2.

\section{Available testing for SARS-CoV-2}

Because the COVID-19 pandemic is caused by a novel coronavirus, physicians started to diagnose this disease by clinical characteristics and laboratory findings rather than laboratory- based molecular methods. However, after viral RNA was isolated, multiple laboratories started to create more accurate diagnostic testing for SARS-CoV2-2. The current available laboratory tests for the virus are: 1) Real-time Reverse Transcriptase Polymerase Chain Reaction (RT$P(R), 2)$ Antigen detection tests and 3) Serology tests, with different uses at different times during the course of the infection ${ }^{43}$.

\section{Real time $R T-P C R$}

The real-time RT-PCR is considered the gold standard and tests the actual presence of viral RNA mostly using samples from nasopharyngeal swabs. However, sputum, bronchoalveolar lavage, oropharynx and feces samples are also being tested for viral presence ${ }^{34,44}$. It is called reverse transcriptase because it transcribes the RNA back to DNA to increase its stability ${ }^{46}$. The WHO created the first protocol in January 2020 based on a 3-step protocol proposed by Corman et al. for the detection of SARS-CoV-2 by real-time RT-PCR. The first line assay identifies the $\mathrm{E}$ gene (small envelope protein) with a limit of detection (LOD=lowest viral concentration detected) of 5.2 RNA copies/reaction and a 95\% Cl: 3.79.6. Then, a confirmatory assay is performed to detect the RdRP gene (RNA dependent RNA-polymerase) with a LOD: 3.8 RNA copies/reaction 95\% Cl: 2.7-7.6 and N gene with a LOD: 8.3 RNA copies/reaction $95 \% \mathrm{Cl}$ : 6.1 $16.3^{45,46}$. The $\mathrm{N}$ gene (nucleocapsid phosphoprotein) is used as confirmation because it is a highly conserved region in coronaviruses and likely to give consistent results ${ }^{47}$. The CDC in the United States has developed a kit that contains a one-step PCR primer-probe for two regions of the viral nucleocapsid phosphoprotein gene 
(N1 and N2) and for the human RNase $\mathrm{P}$ gene to ensure the RNA extraction was successful, differing from the first WHO protocol ${ }^{44}$. Chu et al. proposed another assay workflow consisting of screening the samples for the $\mathrm{N}$ gene and using the ORF1b gene as confirmation. If the latter were to be negative, the study would be inconclusive and further serologic or RNA sequencing studies should be performed ${ }^{50}$. All assays have a high sensitivity and specificity for SARS-CoV-2 needing a low cycle threshold for a positive result and minimal crossreactivity with other types of coronaviruses ${ }^{44}$.

Even though RT-PCR has demonstrated to detect viral presence at low thresholds, it is early in the course of the disease to determine the test's actual sensitivity on COVID-19. The test results can be altered according to the way the sample is handled, the location where the sample was taken and the timing of the test. This could mean that not all negative patients are actually disease free. Some studies have reported cases of patients with an initial negative PCR result from a nasopharyngeal sample, that later developed symptoms and then tested positive from bronchoalveolar lavage samples ${ }^{48,50}$. This false negative rate in early phases is worrisome in the screening of the disease and may result in a failure to isolate patients timely. Furthermore, PCR can be positive in saliva and nasopharyngeal swab on the first 14 days of the disease and then become negative, while fecal PCR can be detected later on and stay present for longer periods of time ${ }^{35}$. Therefore, periodic testing from different tissue samples may help increase the sensitivity and reduce the false negative rate $^{42}$

\section{Serologic testing}

Serologic tests are blood-based tests used to identify antibodies for a specific pathogen at a particular point in time. As stated above, IgM represents an acute infection while IgG a chronic one. There are several assays that can be performed to evaluate the presence of antibodies: 1) Rapid diagnostic testing (RDT): is a qualitative measure of the antibody presence with 30 minutes results that became available through an emergency use authorization by the FDA. According to labeling, it has a sensitivity of $93.8 \%$ and a specificity of $95.6 \%^{51,53}$. Other studies conducted in China indicated that the $\lg \mathrm{G}-\lg M$ combined antibody test kit has a sensitivity of $88.66 \%$ and specificity of $90.63 \%$, suggesting its use as a fast screening tool ${ }^{54}$. However, a study conducted in an emergency room in Italy, used the IgM/lgG RDT on 38 RT-PCR positive acutely ill patients and determined a sensitivity of $18.4 \%$ and a specificity of $91.7 \%$, with a negative predictive value (NPV) of $26.2 \%$ and a positive predictive value (PPV) of $87.5 \%$, thus questioning its use on the early course of the infection ${ }^{55}$. 2)Enzyme-linked immunosorbent assay (ELISA): is a test that can be either qualitative or quantitative and uses whole blood, plasma or serum samples. The test uses a plate coated with viral protein where the samples are incubated. If the antibodies are present, they will bind to the specific protein and this protein-antibody complex would later be detected by binding to a new batch of fluorescent based antibodies ${ }^{53}$. There are some concerns about cross-reactivity of SARS-CoV-2 antibodies and other coronaviruses. Some ongoing studies created an ELISA-based assay to detect antibodies against $\mathrm{N}$ protein, RBD protein and S/S1 proteins which are the main immunologic coronavirus proteins. $\mathrm{S} 1$ was more specific than $S$ and did not cross-react with MERS-CoV but it did with SARS-CoV because it shares $90 \%$ of its amino acid sequencing. The $N$ protein, sharing $92 \%$ of amino acid sequencing, and RBD protein, sharing $73 \%$ of amino acid sequencing with SARS-CoV, were more specific for SARS-CoV-2 than S protein. Therefore, it might be useful to detect antibodies against 2 different proteins in order to confirm the antibody response against SARS-CoV-2 and avoid false negative results $35,46,56,58$. One study recognized that the positive detection rate increased from $51.9 \%$ from a single PCR test to $98.6 \%$ when combined with IgM ELISA assay even in early stages ${ }^{37}$. 3)Neutralization assay: this assay can tell if the antibodies are active against the virus. The virus is cultured on VeroE6 cells and researchers can quantify the antibodies that block viral replication. One study demonstrated that IgG neutralizes the SARSCoV-2 virus at a dilution of 1:40-1:80 and further confirmed the cross-neutralization with SARS-CoV at 1:40 dilutions. The results of this test can take days and might miss antibodies to viral proteins not involved in replication ${ }^{53,56}$. 
Serologic testing has multiple advantages like helping in contact tracing, serologic surveillance and identification of cases that might have had the virus and probably became immune ${ }^{42}$. However, the use of these diagnostic methods depends on the presence of sufficient antibodies in the serum which varies in time. Because humoral kinetics for SARS-CoV-2 are not yet well understood, an accurate protocol to detect immunoglobulins and prevent false negative rates is still needed. However, it would seem that combined RDT can be used alongside nasopharyngeal and sputum RT-PCR on early stages of the disease, followed by the 2-type protein testing of IgM and IgG with ELISA starting on day 5 and continuing the surveillance.

\section{Radiographic testing}

Many studies have described the radiological changes seen on computed tomography (CT) for COVID-19. These changes range from ground-glass opacities, multifocal organizing pneumonia and architectural distortion in a peripheral distribution. Several studies compared the sensitivity of CT to RT-PCR on COVID-19. Fang et al. determined that the sensitivity of chest CT was $98 \%$ while RT-PCR was $71 \%$ with a $p<0.001^{59}$. Tao Ai et al. reported a high sensitivity for chest CT of $97 \%$ based on positive RT-PCR results ${ }^{60}$ and a case report described radiologic testing on $C T$ even before symptom onset, suggesting the use of chest $C T$ as a screening tool $^{61}$. Another radiologic study compared the capacities of different radiologists from China and the United States to differentiate COVID-19 pneumonia from other viral pneumonias on CT. Two hundred and nineteen patients with both SARS-CoV-2 PCR and chest CT positivity were identified from 7 Chinese hospitals and 205 cases with positive Respiratory Panel and CT changes were identified from a hospital in Rhode Island. The 424 radiographic studies were evaluated by the Chinese radiologist while 58 $\mathrm{CT}$ studies were evaluated by the American radiologists. The sensitivity from Chinese radiologists ranged between $72-94 \%$ and specificity from $24-94 \%$. For the American radiologists the sensitivity ranged between $73-93 \%$ and specificity from $93-100 \%$. The most discriminating features for COVID-19 pneumonia were peripheral distribution, ground-glass opacities and vascular thickening. Although
CT has shown high sensitivity when compared to RT-PCR for COVID-19, it may not reveal different patterns for the disease, making it non-specific to differentiate COVID-19 from other viral pneumonias ${ }^{62}$. This is one of the reasons RT-PCR remains the gold-standard test for COVID-19. Furthermore, using CT as a screening method might expose health care workers excessively to the virus. Therefore, the American College of Radiology recommends the use of CT only on hospitalized, symptomatic patients with specific clinical indications for CT with appropriate infection control procedures ${ }^{63}$.

\section{COVID-19 and elective operations}

The rapidly changing situation of COVID-19, the fact that the understanding about the virus is evolving, and that it might be contagious on the incubation and convalescence phases, raises concerns when planning a surgery. Furthermore, the fact that surgery decreases cellmediated immunity, an important mechanism to mitigate viral damage, might deter surgeons from performing the procedure. One retrospective study conducted in Wuhan, China described the case of 34 patients that unintentionally went into surgery during the incubation period of SARS-COV-2 and presented an increased mortality rate of $20.5 \%{ }^{64}$.

Recently, elective surgeries operations have decreased in the United States, especially transplant ssurgeries, since immunosuppressed patients are a particularly vulnerable population. The United Network for Organ Sharing (UNOS) reports the data of current transplant surgeries being performed across the country. From March 8th to April 11th of 2020 the amount of transplant surgeries has declined by $50 \%$, with a specific decrease of $70 \%$ in the case of lung transplant ${ }^{65}$. The impact of COVID-19 on solid organ transplants is uncertain. Up to this date, no donor-derived transmission of SARS-CoV-2 to the recipient has been reported ${ }^{66}$. However, the fact that one study found RNAemia in 15\% of their patients ${ }^{67}$ may raise concerns of the possibility of transmission through organ transplantation as seen in previous coronavirus epidemics. Kumar et al. described a patient who contracted SARS in 2003 through a liver transplant and died, with subsequent infection of 
health-care workers and family members. Therefore, they created a donor screening survey tool based on epidemiologic risk factors to stratify donors according to their risk of SARS exposure and avoid the creation of 'super-spreaders' out of transplant recipients, given the suspicion that they might shed a large amount of virus for longer periods of time ${ }^{68}$.

In some cases, delaying a surgery would greatly increase a patient's probability of dying. Consequently, Stahel et al. proposed a risk-stratification method for elective surgeries by indication and urgency during the COVID-19 pandemic ${ }^{69}$ and Al-Miharraqui et al. suggest that all patients be screened with RT-PCR and antibody measurements 24 hours before surgery in addition to isolation. PCR positive patients would not undergo surgery, PCR -/antibody + patients would undergo surgery with no further testing and PCR -/Antibody - patients would undergo surgery and continue to be tested weekly within their hospital stay ${ }^{70}$.

\section{Proposed battery testing}

At this stage of the pandemic, multiple things remain uncertain. It is too early to fully understand the incidence, prevalence and fatality rate of the infection. For this reason, our current ability to achieve a near $100 \%$ negative predictive value when testing a patient is also uncertain. However, according to the data reviewed in this article, there is a series of measures that can be taken to improve viral detection and increase the negative predictive value. Given the virus' temporal dynamics, it would be reasonable to test the patient at different points in time. Nasopharyngeal swabs and sputum sample RT-PCRs have a high positive rate at early stages of the disease, while fecal RT-PCR becomes positive later on. In addition, either serologic or radiologic testing used together with RT-PCR have shown to improve the sensitivity of the test. This would prevent asymptomatic carriers to undergo surgeries, decreasing the post-operative complications and possible exposure of health care workers to the virus. We propose that a more comprehensive and sequential battery of tests be studied to maximize negative predictive value (Table 1). If at any step of the sequential battery of tests, COVID-19 is diagnosed, the sequential battery is terminated, and the standard of care is to be followed for confirmed COVID-19 patients.

\section{Pre-surgical evaluation}

When considering patients for surgery, we suggest that more tests be performed at different stages to increase negative predictive value. 1) To evaluate the pre-test probability of infection, an epidemiologic questionnaire can be conducted (Table 2). When patients, especially organ donors come from low incidence zones, the negative predictive value of the tests should increase. The Center for Disease Control and Prevention, Atlanta, USA reports the incidence in the United States by region/county. This resource can be consulted to establish the patients' risk according to their recent location ${ }^{71}$. 2) Pulse oximetry testing at rest or during exercise since "silent hypoxemia" has been reported in some cases. 3) When performing molecular testing, bronchoalveolar lavage PCR has shown higher sensitivity at early stages; however, it is more invasive and aerosol-generating, thus not advisable. Nasopharyngeal PCR and sputum/tracheal aspirate PCR (when possible) should be performed on the pre-operative evaluation. 4) Furthermore, the serologic rapid test of $\lg \mathrm{M}$ and $\lg \mathrm{G}$ has shown to increase the diagnostic yield when performed in combination with PCR for viral detection. However, because the actual humoral response for the virus is not well understood and because it is still uncertain whether or not immunoglobulins provide protection for future infections, physicians should be careful when a patient tests positive on serologic tests. At this time, any serologic positivity might imply recent viral exposure, therefore, it is our suggestion that this patient should not undergo surgery. Several months from now, isolated IgG positivity may imply a distant exposure, safe enough to permit surgery. 5) COVID-19 may present radiologic changes on early stages of the disease, so a CT chest without contrast could be considered as a screening tool in high risk patients like transplant recipients.

\section{Post-surgery testing}

Testing should notstop after surgery is performed. The fact that during the incubation stage patients might be 
contagious even when presenting a negative initial RT-PCR test, increases the risk of unintentionally having operated an asymptomatic carrier of the virus. Furthermore, patients with long hospital stays may have increased risk of nosocomial acquisition of SARS-CoV-2. Therefore, continuous monitoring for 2-4 weeks after surgery might increase the detection of the virus in early stages and identify a possible 'super-spreader'. This would allow for the implementation of effective containment measures before releasing the patient from the hospital. 1)During the first 72 hours after surgery, PCR of nasopharyngeal swab and sputum/tracheal aspirate (if possible) should be performed. Since viral shedding on fecal samples has been seen on late stages of the disease, we propose testing viral RNA through PCR on fecal/anal swab samples starting 72 hours after surgery and during the weekly post-surgical evaluations. 2)ELISA test of antibodies on two proteins should also be performed to increase the sensitivity at the weekly post-surgical evaluations.

\section{Donor transplant evaluation}

As stated above, little is known about the possible transmission of SARS-CoV-2 through transplanted organs. However, preventing the use of an organ from an infected donor would be imperative. Kumar et al. describe the approach for donor screening implemented by different countries, including epidemiologic questionnaires and RTPCR on nasopharyngeal swabs and on bronchoalveolar lavage and suggest a phased approach strategy for decreasing transplantation activity ${ }^{72}$. Minimizing donorderived infection in organ transplantation is crucial and so we suggest a more thorough testing protocol on organ donors that includes: RT-PCRs from nasopharyngeal swab, blood, feces or anal swab, and serology testing at two time points 48-72 hours apart; and tracheal aspirate RT-PCR and CT chest without contrast at least once. Regarding transplant recipients, the battery of testing stated on Table 1 should also be performed.

Tabela 1. Timing Of Testing.

\begin{tabular}{|c|c|c|c|c|c|c|c|c|c|}
\hline Time & $\begin{array}{c}\text { Clinical } \\
\text { characteristics }\end{array}$ & $\begin{array}{l}\text { Epidemiologic } \\
\text { characteristics }\end{array}$ & $\begin{array}{l}\text { Pulse } \\
\text { oximetry } \\
\text { (resting } \\
\text { and } \\
\text { upon } \\
\text { walking) }\end{array}$ & $\begin{array}{l}\text { PCR } \\
\text { NPS }\end{array}$ & $\begin{array}{c}\text { PCR } \\
\text { sputum/ } \\
\text { tracheal } \\
\text { aspirate } \\
\text { (when } \\
\text { possible) }\end{array}$ & $\begin{array}{c}\text { PCR } \\
\text { fecal/ } \\
\text { anal } \\
\text { swab }\end{array}$ & $\begin{array}{c}\text { Rapid } \\
\text { IgM/lgG }\end{array}$ & ELISA & $\begin{array}{l}\text { Chest CT } \\
\text { without } \\
\text { contrast }\end{array}$ \\
\hline $\begin{array}{c}\text { Within } \\
24 \mathrm{~h} \\
\text { before } \\
\text { surgery }\end{array}$ & $\begin{array}{l}\text { If positive, no } \\
\text { surgery is } \\
\text { performed }\end{array}$ & $\begin{array}{l}\text { Epidemiologic } \\
\text { questionnaire } \\
\text { (Table 2) }\end{array}$ & yes & yes & yes & & $\begin{array}{c}\text { yesà if } \\
\text { lgM/lgG } \\
\text { positive, } \\
\text { consider } \\
\text { deferring } \\
\text { surgery }\end{array}$ & & $\begin{array}{c}\text { Yes: } \\
\text { especially } \\
\text { in } \\
\text { transplant } \\
\text { candidates }\end{array}$ \\
\hline $\begin{array}{l}72 \mathrm{~h} \text { after } \\
\text { surgery }\end{array}$ & & & yes & yes & yes & yes & yes & & \\
\hline $\begin{array}{c}\text { Weekly } \\
\text { check-ups } \\
\text { for 2-4 } \\
\text { weeks }\end{array}$ & & & yes & yes & yes & yes & & yes & \\
\hline
\end{tabular}

NPS: nasopharyngeal.

Tabela 2. Epidemiologic Questionnaire.
1. "Have you or anybody that you are in contact with traveled?"
-If so, where and when?
2. "Have you been in direct contact with anybody known to have COVID-19?"
3. "Do you have a fever, cough, sore throat, runny nose, and/or shortness of breath?"
4. "Have you tested positive for COVID-19?"
5. "Have you loss any sense of smell or taste?"
6. "Which county do you currently reside or have been for the last 2 weeks?" 


\section{CONCLUSION}

The SARS-CoV-2 pandemic has become a global emergency. Multiple studies hypothesize that it is a widely contagious virus that can be spread even on asymptomatic and recovery phases. Viral shedding has been found on different samples including: bronchoalveolar lavage, sputum, nasopharyngeal swab, oropharyngeal swab, blood and feces at different stages of the infection with varying sensitivities. Antibody testing has also varied in sensitivity depending on the test and the phase of the disease. Therefore, we propose that conducting a battery of tests sequentially from different tissue samples would increase the negative predictive value and decrease the false negative rate. A low false negative rate is crucial to resume elective surgeries and increase transplantation activity. We encourage the scientific community to continue improving the testing protocols to allow physicians to perform necessary surgeries in the safest way possible.

\section{MAIN MESSAGES}

- SARS-CoV-2 can be transmitted on both asymptomatic and recovery phases, requiring the implementation of better epidemiologic and isolation measures.

- COVID-19 dynamics change throughout time

- Current available testing lack high sensitivity and specificity for SARS-COV-2

- Proposed sequential battery of testing to increase negative predictive value on patients being evaluated for surgeries

\title{
R E S U M O
}

\begin{abstract}
O SARS-CoV-2 é um novo vírus que provou ser altamente contagioso. A dinâmica viral específica e a resposta imunológica ao vírus ainda não foram totalmente definidas e a determinação da sensibilidade e especificidade dos métodos de teste disponíveis ainda está em andamento. Este estudo examina as informações publicadas sobre os métodos de testagem e conclui que o rendimento dos testes COVID-19 muda de acordo com o tipo de amostra e com o tempo de progressão da doença. Propomos uma bateria sequencial de testes, que consiste em um levantamento epidemiológico, testes de RT-PCR, testes sorológicos e tomografia computadorizada de tórax em candidatos a cirurgia, que podem aumentar o valor preditivo negativo e facilitar procedimentos cirúrgicos.
\end{abstract}

Palavras chave: Transplante. Coronavirus. Valor Preditivo dos Testes.

\section{REFERENCES}

1. World Health Organization Coronavirus disease (COVID-19) situation report. https://www.who. int/emergencies/diseases/novel-coronavirus-2019/ situation-reports

2. Centers for Disease Control and Prevention (CDC): Interim Clinical Guidance for Management of Patients with Confirmed Coronavirus Disease (COVID-19). https://www.cdc.gov/coronavirus/2019-ncov/ hcp/clinical-guidance-management-patients. html\#clinical-presentation

3. et al. The origin, transmission and clinical therapies on coronavirus disease 2019 (COVID-19) outbreak an update on the status. Mil Med Res. 2020; 7: 11. doi: 10.1186/s40779-020-00240-0. https://www. ncbi.nlm.nih.gov/pmc/articles/PMC 7068984/

4. Lechien JR, Chiesa-Estomba CM, De Siati DR, Horoi $M$, Le Bon SD, Rodriguez A, et al. Olfactory and gustatory dysfunctions as a clinical presentation of mild-to-moderate forms of the coronavirus disease (COVID-19): a multicenter European study. Eur Arch Otorhinolaryngol. 2020:1-11. doi.org/10.1007/ s00405-020-05965-1

5. Khafaie MA, Rahim F. Cross-Country Comparison of Case Fatality Rates of COVID-19/SARS-COV-2. Osong Public Health Res Perspect. 2020;11(2):74-80. doi: 10.24171/j.phrp.2020.11.2.03. https://www. ncbi.nlm.nih.gov/pmc/articles/PMC 7104689/\#s1ophrp-11-74 
6. Wu Z, McGoogan JM. Characteristics of and Important Lessons From the Coronavirus Disease 2019 (COVID-19) Outbreak in China: Summary of a Report of 72314 Cases From the Chinese Center for Disease Control and Prevention. JAMA. 2020;323(13):1239-42. doi:10.1001/ jama.2020.2648

7. CDC COVID-19 Response Team. Severe Outcomes Among Patients with Coronavirus Disease 2019 (COVID-19) - United States, February 12March 16, 2020. MMWR Morb Mortal Wkly Rep. 2020;69(12):343-6.

8. Epidemiology Working Group for NCIP Epidemic Response, Chinese Center for Disease Control and Prevention. [The epidemiological characteristics of an outbreak of 2019 novel coronavirus diseases (COVID-19) in China]. Zhonghua Liu Xing Bing Xue Za Zhi. 2020;41(2):145-151. Chinese.

9. Li Q, Guan X, Wu P, Wang X, Zhou L, Tong Y, et al. Early Transmission Dynamics in Wuhan, China, of Novel Coronavirus-Infected Pneumonia. N Engl J Med. 2020;382(13):1199-207. doi: 10.1056/ NEJMoa2001316

10. Chan JF, Yuan S, Kok KH, To KK, Chu H, Yang J, et al. A familial cluster of pneumonia associated with the 2019 novel coronavirus indicating person-to-person transmission: a study of a family cluster. Lancet. 2020 Feb 15;395(10223):514-523. https://doi.org/10.1016/S0140-6736(20)301549.https://www. thelancet.com/action/ showPdf?pii=S0140-6736\%2820\%2930154-9

11. Phan LT, Nguyen TV, Luong QC, Nguyen TV, Nguyen HT, Le HQ, et al. Importation and Humanto-Human Transmission of a Novel Coronavirus in Vietnam. N Engl J Med. 2020; 382:872-874. DOI: 10.1056/NEJMc2001272. https://www.nejm.org/ doi/full/10.1056/NEJMc2001272?query=featured_ home

12. Han $Y$, Yang $H$. The transmission and diagnosis of 2019 novel coronavirus infection disease (COVID-19): A Chinese perspective. J Med Virol. 2020;92(6):639-44. doi.org/10.1002/jmv.25749. https://onlinelibrary.wiley.com/doi/full/10.1002/ jmv.25749

13. Yu P, Zhu J, Zhang Z, Han Y. A Familial Cluster of Infection Associated With the 2019 Novel Coronavirus Indicating Possible Person-to-Person Transmission During the Incubation Period. J Infect Dis. 2020;221(11):1757-61. doi: 10.1093/ infdis/jiaa077. https://www.ncbi.nlm.nih.gov/pmc/ articles/PMC7107453/

14. Ghinai I, McPherson TD, Hunter JC, Kirking HL, Christiansen D, Joshi K, Rubin R, Morales-Estrada S, Black SR, Pacilli M, Fricchione MJ, Chugh RK, Walblay KA, Ahmed NS, Stoecker WC, Hasan NF, Burdsall DP, Reese HE, Wallace M, Wang C, Moeller D, Korpics J, Novosad SA, Benowitz I, Jacobs MW, Dasari VS, Patel MT, Kauerauf J, Charles EM, Ezike NO, Chu V, Midgley CM, Rolfes MA, Gerber SI, LuX, Lindstrom S, Verani JR, Layden JE; Illinois COVID-19 Investigation Team. First known person-to-person transmission of severe acute respiratory syndrome coronavirus 2 (SARS-CoV-2) in the USA. Lancet. 2020;395(10230):1137-1144. doi.org/10.1016/ S0140-6736(20)30607-3. https://www.thelancet. com/pdfs/journals/lancet/PIIS0140-6736(20)306073.pdf

15. Wrapp D, Wang N, Corbett KS, Goldsmith JA, Hsieh $\mathrm{CL}$, Abiona O, et al. Cryo-EM structure of the 2019nCoV spike in the prefusion conformation. Science. 2020 Mar 13;367(6483):1260-3. doi: 10.1126/ science.abb2507. https://science.sciencemag.org/ content/367/6483/1260

16. van Doremalen $\mathrm{N}$, Bushmaker $\mathrm{T}$, Morris $\mathrm{DH}$, Holbrook MG, Gamble A, Williamson BN, et al. Aerosol and Surface Stability of SARSCoV-2 as Compared with SARS-CoV-1. N Engl J Med. 2020;382(16):1564-1567. doi: 10.1056/ NEJMc2004973. https://www.nejm.org/doi/ full/10.1056/NEJMc2004973?query=recirc_ mostViewed_railB_article

17. Kampf G, Todt D, Pfaender S, Steinmann E. Persistence of coronaviruses on inanimate surfaces and their inactivation with biocidal agents. J Hosp Infect. 2020;104(3):246-51. doi. org/10.1016/j.jhin.2020.01.022 0195-6701/. https://www.journalofhospitalinfection.com/action/ showPdf?pii=S0195-6701\%2820\%2930046-3

18. Special Expert Group for Control of the Epidemic of Novel Coronavirus Pneumonia of the Chinese 
Preventive Medicine Association. [An update on the epidemiological characteristics of novel coronavirus pneumonia COVID-19]. Zhonghua Liu Xing Bing Xue Za Zhi. 2020;41(2):139-44.

19. Lo IL, Lio $\mathrm{CF}, \mathrm{n}$ Cheong $\mathrm{HH}$, Lei $\mathrm{Cl}$, Cheong $\mathrm{TH}$, Zhong $X$, et al. Evaluation of SARS-CoV-2 RNA shedding in clinical specimens and clinical characteristics of 10 patients with COVID-19 in Macau. Int J Biol Sci. 2020; 16(10):1698-1707. doi: 10.7150/ijbs.45357. https://www.ncbi.nlm.nih.gov/ pmc/articles/PMC7098032/

20. Guan WJ, Ni ZY, Hu Y, Liang WH, Ou CQ, He JX, Liu L, Shan H, Lei CL, Hui DSC, Du B , Li LJ, Zeng G, Yuen $K Y$, Chen RC, Tang CL, Wang T, Chen PY, Xiang J, Li SY, Wang JL, Liang ZJ, Peng YX, Wei L, Liu Y, Hu YH, Peng P, Wang JM, Liu JY, Chen Z, Li G, Zheng ZJ , Qiu SQ, Luo J, Ye CJ, Zhu SY, Zhong NS; China Medical Treatment Expert Group for Covid-19. Clinical Characteristics of Coronavirus Disease 2019 in China. N Engl J Med. 2020;382(18):1708-20. doi: 10.1056/NEJMoa2002032. https://www.nejm.org/ doi/full/10.1056/NEJMoa2002032

21. Lauer SA, Grantz KH, Bi Q, Jones FK, Zheng Q, Meredith HR, et al. The Incubation Period of Coronavirus Disease 2019 (COVID-19) From Publicly Reported Confirmed Cases: Estimation and Application. Ann Intern Med. 2020;172(9):57782. https://annals.org/aim/fullarticle/2762808/ incubation-period-coronavirus-disease-2019-covid19-from-publicly-reported

22. Hu Z, Song $C, X u C$, Jin $G, C$ hen $X, X u X$, et al. Clinical characteristics of 24 asymptomatic infections with COVID-19 screened among close contacts in Nanjing, China. Sci China Life Sci. 2020;63(5):70611. doi:org/10.1007/s11427-020-1661-4. https:// link.springer.com/article/10.1007\%2Fs11427-0201661-4\#citeas

23. Lai CC, Liu YH, Wang $C Y$, Wang $Y H$, Hsueh SC, Yen MY, et al. Asymptomatic carrier state, acute respiratory disease, and pneumonia due to severe acute respiratory syndrome coronavirus 2 (SARS-CoV-2): Facts and myths. I Microbiol Immunol Infect. 2020;53(3):404-12. https:// www.sciencedirect.com/science/article/pii/ S1684118220300402?via\%3Dihub
24. Bai $Y, Y a o L$, wei $T$, Tian $F$, Jin $D Y$, Chen $L$, et al. Presumed Asymptomatic Carrier Transmission of COVID-19. JAMA. 2020;323(14):1406-7. doi:10.1001/jama.2020.2565. https://jamanetwork. com/journals/jama/fullarticle/2762028

25. Rothe C, Schunk M, Sothmann P, Bretzel G, Froeschl G, Wallrauch C, et al. Transmission of 2019nCoV Infection from an Asymptomatic Contact in Germany. N Engl J Med. 2020;382(10):970-1.

26. Wei WE, Li Z, Chiew CJ, Yong SE, Toh MP, Vernon J Lee VJ. Presymptomatic Transmission of SARSCoV-2 Singapore, January 23-March 16, 2020. MMWR Morb Mortal Wkly Rep. 2020;69(14);4115. https://www.cdc.gov/mmwr/volumes/69/wr/ mm6914e1.htm

27. Zou L, Ruan F, Huang M, Liang L, Huang $H$, Hong $Z$, et al. SARS-CoV-2 viral load in upper respiratory specimens of infected patients. N Engl J Med. 2020;382(12):1177-9. https://doi.org/10.1056/ NEJMc2001737

28. Wang $Y$, Liu $Y$, Liu L, Wang $X$, Luo N, Li L. Clinical Outcomes in 55 Patients With Severe Acute Respiratory Syndrome Coronavirus 2 Who Were Asymptomatic at Hospital Admission in Shenzhen, China. J Infect Dis. 2020;221(11):17704. doi: 10.1093/infdis/jiaa119. https://academic. oup.com/jid/advance-article/doi/10.1093/infdis/ jiaa119/5807958

29. Chang $D, X u H$, Rebaza A, Sharma L, Dela Cruz CS. 2020. Protecting health-care workers from subclinical coronavirus infection. Lancet Respir Med. 2020;8(3):e13. doi:org/10.1016/ S22132600(20)30066-7

30. Pan Y, Zhang D, Yang P, Poon LLM, Wang Q. Viral load of SARS-CoV-2 in clinical samples. Lancet Infect Dis. 2020;20(4):411-2. doi:org/10.1016/ S1473-3099(20)30113-4. https://www.thelancet. com/pdfs/journals/laninf/PIIS1473-3099(20)301134.pdf

31. Qian GQ, Chen XQ, Lv DF, Ma AHY, Wang LP, Yang $N B$, et al. Duration of SARS-CoV-2 viral shedding during COVID-19 infection. Infect Dis (Lond). 2020;52(7):511-2. doi:10.1080/23744235.2020.1 748705

32. Zhou F, Yu T, Du R, Fan G, Liu Y, Liu Z, et al. Clinical 
course and risk factors for mortality of adult inpatients with COVID-19 in Wuhan, China: a retrospective cohort study. Lancet. 2020;395(10229):1054-62. doi:10.1016/ S0140-6736(20)30566-3

33. Liu Y, Yan LM, Wan L, Xiang TX, Le A, Liu JM, et al. Viral dynamics in mild and severe cases of COVID-19. Lancet Infect Dis. 2020;20(6):6567. doi:org/10.1016/ S1473-3099(20)30232-2. https://www.thelancet.com/journals/laninf/article/ PIIS1473-3099(20)30232-2/fulltext

34. Wang W, Xu Y, Gao R, , Lu R, Han K, Wu G, et al. Detection of SARS-CoV-2 in Different Types of Clinical Specimens. JAMA. 2020;323(18):1843-4. doi:10.1001/jama.2020.3786.

35. Zhang $W, D u R H$, Li B, Zheng XS, Yang XL, Hu $B$, et al. Molecular and serological investigation of 2019-nCoV infected patients: implication of multiple shedding routes. Emerg Microbes Infect. 2020;9(1):386-9. doi.org/10.1080/22221751.2020 .1729071

36. Thevarajan I, NguyenTHO, Koutsakos M, Druce J, Caly L, van de Sandt CE, et al. Breadth of concomitant immune responses prior to patient recovery: a case report of non-severe COVID-19. Nat Med. 2020;26(4):453-5. doi.org/10.1038/ s41591-020-0819-2.

37. Gui L, Ren L, Tang S, Xiao M, Chang D, Yang F, et al. Profiling Early Humoral Response to Diagnose Novel Coronavirus Disease (COVID-19). Clin Infect Dis. 2020; ciaa310. doi.org/10.1093/cid/ciaa310

38. To KKW, Tsang OTY, Leung WS, Tam AR, Wu TC, Lung DC, et al. Temporal profiles of viral load in posterior oropharyngeal saliva samples and serum antibody responses during infection by SARSCoV-2: an observational cohort study. Lancet Infect Dis. 2020;20(5):565-74. doi.org/10.1016/ S14733099(20)30196-1. https://www.thelancet.com/ pdfs/journals/laninf/PIIS1473-3099(20)30196-1.pdf

39. Du Z, Zhu F, Guo F, Yang B, Wang T. Detection of antibodies against SARS-CoV-2 in patients with COVID-19. J Med Virol. 2020;10.1002/jmv.25820. doi.org/10.1002/jmv.25820

40. Zhao J, Yuan Q, Wang H, Liu W, Liao X, Su Y, et al. Antibody responses to SARS-CoV-2 in patients of novel coronavirus disease 2019. Clin Infect Dis. 2020;ciaa344. doi:org/10.1093/cid/ciaa344

41. Bao L, Deng W, Gao H, Xiao C, Liu J, Xue J, et al. Reinfection could not occur in SARS-CoV-2 infected rhesus macaques. doi: https://doi. org/10.1101/2020.03.13.990226

42. Patel R, Babady E, Theel ES, Storch GA, Pinsky $B A$, St George $K$, et al. Report from the American Society for Microbiology COVID-19 International Summit, 23 March 2020: Value of Diagnostic Testing for SARS-CoV-2/COVID-19 [editorial]. mBio. 2020;11(2):e00722-20. doi:10.1128/mBio.0072220

43. Cheng MP, Papenburg J, Desjardins M, Kanjilal S, Quach C, Libman M, et al. Diagnostic Testing for Severe Acute Respiratory Syndrome-Related Coronavirus-2: A Narrative Review. Ann Intern Med. 2020; Epub ahead of print 13 April 2020. doi: https://doi.org/10.7326/M20-1301

44. To KKW, Tsang OTY, Yip CCY, Chan KH, Wu TC, Chan JMC, et al. Consistent Detection of 2019 Novel Coronavirus in Saliva. Clin Infect Dis. 2020;ciaa149. doi.org/10.1093/cid/ciaa149

45. Corman VM, Landt O, Kaiser M, Molenkamp R, Meijer A, Chu DK, et al. Detection of 2019 novel coronavirus (2019-nCoV) by real-time RT-PCR. Euro Surveill. 2020;25(3):2000045. doi: 10.2807/15607917.ES.2020.25.3.2000045

46. Udugama B, Kadhiresan $P$, Kozlowski HN, Malekjahani A, Osborne M, Li VYC, et al. Diagnosing COVID-19: The Disease and Tools for Detection. ACS Nano. 2020;14(4):3822-35. doi: 10.1021/ acsnano.0c02624

47. John Hopkins University. 2020. Comparison of National RT-PCR Primers, Probes, and Protocols for SARS-CoV-2 Diagnostics. April 13, 2020. https://www.centerforhealthsecurity.org/resources/ COVID-19/COVID-19-fact-sheets/200410-RT-PCR. pdf

48. Han $Y$, Yang $H$. The transmission and diagnosis of 2019 novel coronavirus infection disease (COVID-19): A Chinese perspective. J Med Virol. 2020;92(6):639-44.doi.org/10.1002/jmv.25749

49. Winichakoon $P$, Chaiwarith $R$, Liwsrisakun C, Salee P, Goonna A, Limsukon A, et al. Negative Nasopharyngeal and Oropharyngeal Swab 
Does Not Rule Out COVID -19. J Clin Microbiol. 2020;58(5):e00297-20. doi:10.1128/JCM.0029720

50. Li Y, Yao L, Li J, Chen L, Song Y, Cai Z, et al. Stability issues of RT-PCR testing of SARS-CoV-2 for hospitalized patients clinically diagnosed with COVID-19. J Med Virol. 2020;92(7):903-8. doi. org/10.1002/jmv.25786

51. Chu DKW, Pan Y, Cheng SMS, Hui KPY, Krishnan $P$, Liu $Y$, et al. Molecular Diagnosis of a Novel Coronavirus (2019-nCoV) Causing an Outbreak of Pneumonia. Clin Chem. 2020;66(4):549-55. doi: 10.1093/clinchem/hvaa029

52. Otto MA. 2020 FDA Grants Emergency Authorization for First Rapid Antibody Test for COVID-19. April 04, 2020. https://www.medscape. com/viewarticle/928150

53. Johns Hopkins University.2020. Serology-based tests for COVID-19. April 2, 2020. http://www. centerforhealthsecurity.org/resources/COVID-19/ serology/Serology-based-tests-for-COVID-19.html

54. Li Z, Yi Y, Luo $X$, Xiong $N$, Liu $Y$, Li S, et al. Development and clinical application of a rapid IgM-IgG combined antibody test for SARS-CoV-2 infection diagnosis. J Med Virol. 2020;10.1002/ jmv.25727. doi:10.1002/jmv.25727

55. Cassaniti I, Novazzi F, Giardina F, Salinaro F, Sachs M, Perlini S, Bruno R, Mojoli F, Baldanti F; Members of the San Matteo Pavia COVID-19 Task Force. Performance of VivaDiag COVID-19 IgM/lgG Rapid Test is inadequate for diagnosis of COVID-19 in acute patients referring to emergency room department. J Med Virol. 2020;10.1002/jmv.25800. doi:10.1002/ jmv. 25800

56. Zhou $P$, Yang $X L$, Wang $X G$, Hu B, Zhang L, Zhang $W$, et al. A pneumonia outbreak associated with a new coronavirus of probable bat origin. Nature. 2020;579(7798):270-3. doi:org/10.1038/s41586020-2012-7

57. Okba NMA, Müller MA, Li W, Wang C, GeurtsvanKessel $\mathrm{CH}$, Corman VM, et al. Severe acute respiratory syndrome coronavirus specific antibody responses in coronavirus disease 2019 patients. Emerg Infect Dis.2020;26(7):1478-1488. doi:org/10.3201/eid2607.200841.
58. Lv H, Wu NC, Tsang OTY, Yuan M, Perera RAPM, Leung WS, et al. Cross-reactive antibody response between 2 SARS-CoV-2 and SARS-CoV infections. bioRxiv. 2020; 2020.03.15.993097; doi: https://doi. org/10.1101/2020.03.15.993097

59. Fang $Y$, Zhang $H$, Xie J, Lin $M$, Ying $L$, Pang $P$, et al. Sensitivity of Chest CT for COVID-19: comparison to RT-PCR. Radiology. 2020;200432. doi:org/10.1148/ radiol.2020200432

60. Ai T, Yang Z, Hou H, Zhan C, Chen C, Lv W, et al. Correlation of Chest $C T$ and RT-PCR Testing in Coronavirus Disease 2019 (COVID-19) in China: A Report of 1014 Cases. Radiology. 2020;200642. doi.org/10.1148/radiol.2020200642

61. Lin C, Ding Y, Xie B, Sun Z, Li X, Chen Z, et al. Asymptomatic novel coronavirus pneumonia patient outside Wuhan: The value of CT images in the course of the disease. Clin Imaging. 2020;63:79. https://doi.org/10.1016/j.clinimag.2020.02.008

62. Bai HX, Hsieh B, Xiong Z, Halsey K, Choi JW, Linh TM, et al. Performance of radiologists in differentiating COVID-19 from viral pneumonia on chest CT. Radiology. 2020;200823. doi:org/10.1148/ radiol.2020200823

63. ACR Recommendations for the use of Chest Radiography and Computed Tomography (CT) for Suspected COVID-19 Infection. March 112020. https://www.acr.org/Advocacy-and-Economics/ ACR-Position-Statements/Recommendationsfor-Chest-Radiography-and-CT-for-SuspectedCOVID19-Infection

64. Lei S, Jiang F, Su W, Chen C, Chen J, Mei W, et al. Clinical characteristics and outcomes of patients undergoing surgeries during the incubation period of COVID-19 infection. EClinicalMedicine. 2020;21:100331.https://doi.org/10.1016/j. eclinm.2020.100331

65. Current state of donation and transplantation. 2020. United Network for Organ Sharing (UNOS). https://unos.org/covid/

66. Michaels MG, La Hoz RM, Danziger-Isakov L, Blumberg EA, Kumnar D, Green M, et al. Coronavirus disease 2019: implications of emerging infections for transplantation. Am J Transplant. 2020 Feb 24. doi:10.1111/ajt.15832 
67. Huang $C$, Wang $Y$, Li X, Ren L, Zhao J, Hu Y, et al. Clinical features of patients infected with 2019 novel coronavirus in Wuhan, China. Lancet. 2020;395(10223):497-506. doi.org/10.1016/ S0140-6736(20)30183-5

68. Kumar D, Tellier R, Draker R, Levy G, Humar A. Severe Acute Respiratory Syndrome (SARS) in a Liver Transplant Recipient and Guidelines for Donor SARS Screening. Am J Transplant. 2003;3(8):977-81. doi. org/10.1034/j.1600-6143.2003.00197.x

69. Stahel PF. How to risk-stratify elective surgery during the COVID-19 pandemic?.Patient Saf Surg. 2020;14:8. doi: 10.1186/s13037-020-00235-9

70. Al-Muharraqi MA. Testing recommendation for

Received in: 27/05/2020

Accepted for publication: 01/06/2020

Conflict of interest: no.

Funding source: none.
COVID-19 (SARS-CoV-2) in patients planned for surgery - continuing the service and 'suppressing' the pandemic [editorial]. $\mathrm{Br} J$ Oral Maxillofac Surg. 2020;58(5):503-505. doi: 10.1016/j. bjoms.2020.04.014

71. Cases of Coronavirus Disease (COVID-19) in the U.S. 2020. https://www.cdc.gov/ coronavirus/2019-ncov/cases-updates/cases-in us.html\#anchor_1586784349

72. Kumar D, Manuel O, Natori Y, Egawa H, Grossi P, Han SH, et al. COVID-19: A global transplant perspective on successfully navigating a pandemic. Am J Transplant. 2020 Mar 23;10.1111/ajt. 15876. doi.org/10.1111/ajt.15876

\section{Mailing address:}

Neeraj Sinha

E-mail: nxs994@med.miami.edu / galubalayla@gmail.com

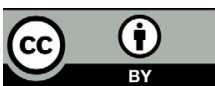

